\title{
Endothelin A receptor-like immunoreactivity on the basal infoldings of rat renal tubules and collecting ducts*
}

\author{
Toshiharu Yamamoto, ${ }^{1,}$, Hirohumi Suzuki ${ }^{3}$, Yukari Kubo³, Aya Matsumoto ${ }^{3}$, and \\ Haruko Uemura ${ }^{1}$ \\ ${ }^{1}$ Department of Human Biology and ${ }^{2}$ Research Center of Brain and Oral Science, Kanagawa Dental College, Yokosuka; \\ and ${ }^{3}$ Department of Biology, Fukuoka University of Education, Fukuoka, Japan
}

Summary. We investigated the distribution of endothelin $A\left(E_{A}\right)$ receptor-like immunoreactivity in the rat kidney using affinity-purified antibodies against amino acid residues 403-417 of the rat $\mathrm{ET}_{\mathrm{A}}$ receptor modified by the multiple antigen peptide complex system. Western blot analysis using the affinity-purified anti-ET $T_{A}$ antibody detected bands of approximately 47.3 and $64.5 \mathrm{kDa}$ in the rat kidney. By light microscopy, $\mathrm{ET}_{\mathrm{A}}$ receptorlike immunoreactivity was seen in the basal side of the renal tubules and collecting ducts. The most intense immunoreactivity was present in the distal renal tubules and inner medullary collecting ducts. In addition to the basal infoldings, immunoreactive puncta were scattered in the epithelial cells of the renal tubules and collecting ducts. Specimens prepared using the pre-embedding method were examined by electron microscopy, and some immunopositive signals were seen on the basal infodings of the renal tubules and collecting ducts. The lengths of immunopositive cytoplasmic membrane were far longer in the distal tubules and inner medullary collecting ducts than in the proximal tubules and outer medullary collecting

Received January 21, 2008

* A part of this study was supported by an Open Research Center subsidy (H18) from MEXT.

Address for correspondence: ToshiharuYamamoto, Ph. D., Department of Human Biology, Kanagawa Dental College, Inaokacho 82, Yokosuka 238-8580, Japan

Tel: +81-46-822-8833, Fax: +81-46-822-8832

E-mail: yumtoshi@kdcnet.ac.jp ducts. Immunopositive signals were also sometimes observed in the thick portion of Henle's loop, but never in the thin portion. We have not previously detected immunopositive signals on the renal vascular systems with the antibody used here. These results suggest that endothelin acts on the basal infoldings through the $\mathrm{ET}_{\mathrm{A}}$ receptor, particularly in the distal tubules and inner medullary collecting ducts, although involvement of the $\mathrm{ET}_{\text {в }}$ receptor cannot be excluded.

\section{Introduction}

Endothelin (ET) has many physiological roles, including vasoconstriction, mitogenic effects, and the modification of pituitary hormone secretion (Simonson and Dunn, 1990; Naruse et al., 1994). There are at least three distinct isoforms - ET-1, ET-2, and ET-3. Receptors for endothelins have been cloned and classified into three types, $\mathrm{ET}_{\mathrm{A}}, \mathrm{ET}_{\mathrm{B}}$, and $\mathrm{ET}_{\mathrm{C}}$. The $\mathrm{ET}_{\mathrm{A}}$ receptor has a higher affinity for ET-1 than for ET-3, the ETB receptor has an equal affinity for ET-1 and ET-3, and the ETC receptor has a higher affinity for ET-3 (Masaki et al., 1991; Karne et al., 1993). Endothelin binding has been extensively studied in various organs using $\left[{ }^{125} \mathrm{I}\right] \mathrm{ET}$ combined with agonists and antagonists, the kidney being one of the most extensively studied organs for the distribution of endothelin and its receptors. Evidence of renal ET biosynthesis and binding suggests the possibility of a local role of ET-1 in the modulation of glomerular and tubular functions (see Rubanyi and Polokoff, 1994). Several lines of study indicate that endothelin in the kidney originates primarily in renal tubular cells (Kakui et al., 2004) although there are quantitative and qualitative differences between nephron segments and between species. With 
regard to ET receptors, it has been shown that the $\mathrm{ET}_{\mathrm{A}}$ receptor is the predominant type in the renal vasculature, mainly in smooth muscle cells, and that the $\mathrm{ET}_{\mathrm{B}}$ receptor is located in renal tubules and collecting ducts in addition to endothelial cells lining the renal vasculature (Hori et al., 1992; Terada et al., 1992) and podocytes (Yamamoto et al., 2002). However, recent findings on the distribution of the $\mathrm{ET}_{\mathrm{A}}$ receptor are highly conflicting. For example, one immunohistochemical study reported the presence of the $\mathrm{ET}_{\mathrm{A}}$ receptor in the renal tubules and collecting ducts (Wendel et al., 2006), whereas another did not (Kuc and Dapenport, 2004). Moreover, an association of the $\mathrm{ET}_{\mathrm{A}}$ receptor with collecting duct functions was suggested from observations made using mice with a knockout of the collecting duct-specific ETA receptor $(\mathrm{Ge}$ et al., 2005). Thus, there is a need to clarify the detailed distribution of the $\mathrm{ET}_{\mathrm{A}}$ receptor in the kidney. The present report describes our findings on the distribution of the $\mathrm{ET}_{\mathrm{A}}$ receptor in the rat kidney by light and electron immunomicroscopy with an affinity-purified antibody raised in our laboratory - against a partial peptide of the $\mathrm{C}$-terminal portion of the rat $\mathrm{ET}_{\mathrm{A}}$ receptor.

\section{Materials and Methods}

Experiments were performed under the authority of the Ethics Committee of Kanagawa Dental College, employing guidelines established by this committee.

\section{Antigen preparation and production of antisera}

A peptide corresponding to amino acid residues 403417 (a cytoplasmic domain) of the rat $\mathrm{ET}_{\mathrm{A}}$ receptor, designated as the ETA peptide, was synthesized (Accord Co. Ltd., Tokyo). This part of the peptide shares the minimum amount of homology with the rat $\mathrm{ET}_{\text {в }}$ receptor. A sequence comparison of the synthetic ETA peptide revealed that it shares $66 \%$ homology with a phage resistance gene of Lactococcus lactis lactis (a Prokaryota) and a subtype of the $\mathrm{ET}_{\mathrm{A}}$ receptor, $\mathrm{ET}_{\mathrm{Ax}}$ endothelin receptor cloned from the Xenopus heart (Kumar et al., 1994). It also has $53 \%$ homology with the glycerol kinase of Escherichia coli and clathrin of Saccharomyces cerevisiae (a Fungi) based on data in the PRF-SEQDB database. The purity of the synthetic peptides was tested by high performance liquid chromatography (HPLC) analysis, which revealed a single peak. The peptide was modified by the multiple antigen peptide complex system (MAP) (Tam and Lu, 1989). Six guinea pigs were used for immunization, with one $\mathrm{ml}$ of pre-immune serum collected from each animal prior to the start of immunization. The first immunization used an emulsion of Freund's complete adjuvant (Difco Labs., MI, USA) and MAP-modified $\mathrm{ET}_{\mathrm{A}}$ peptide solution $(2 \mathrm{mg} / \mathrm{m} l)$ at a ratio of $1: 1$. Each guinea pig was injected subcutaneously with $0.2,0.2,0.4,0.4$, 0.5 or $0.5 \mathrm{ml}$ of the emulsion while the animal was under ether anesthesia. Booster injections of the same volume as the initial injection were given to each aminal fortnightly, replacing the complete adjuvant with incomplete adjuvant (Difco Labs.). Three days after each booster, $1 \mathrm{ml}$ of blood was collected and its serum was tested with sections of the rat kidney. When immunostaining was obtained at a dilution of 1:1,000, antisera were used for affinity purification.

\section{Larsson's spot test}

The specificity of the selected antisera was tested using the membrane blotting method (Larsson et al., 1981). Various artificial protein samples were blotted on a nitrocellulose membrane (Pharmacia Biotech, Uppsala, Sweden): MAPmodified ET $_{\text {A }}$ peptide; bovine serum albumin (BSA)conjugated ETA peptide with glutaraldehyde; MAPmodified ЕTв peptide corresponding to amino-acid residues 425-439 of the rat $\mathrm{ET}_{\text {в }}$ receptor (Sakurai et al., 1990); BSA-conjugated $\mathrm{ET}_{\text {в }}$ peptide with glutaraldehyde; and BSA-conjugated arginine-vasopressin (AVP; as a neuropeptide) with glutaraldehyde. The membrane was dried, blocked with $3 \% \mathrm{BSA}$ in a $0.1 \mathrm{M}$ sodium phosphate buffer (PB; $\mathrm{pH} 7.4)$, and stained with pre-immune serum $(1: 1,000)$ and antiserum $(1: 1,000)$, followed by incubation with biotinylated anti-guinea pig $\operatorname{IgG}(1: 1,000$; Vector Laboratories, Burlingame, CA, USA) and an avidinbiotin-horseradish peroxidase complex (ABC; Vector Laboratories) diluted to 1:1,000. The peroxidase complex was detected by incubation of the membrane with a $0.02 \%$ 3, 3'-diaminobenzidine tetrahydrochloride (DAB) solution containing $0.005 \%$ hydrogen peroxide and $0.6 \%$ ammonium nickel sulfate for 5-10 $\mathrm{min}$.

\section{Affinity purification of antibodies}

ET $_{\mathrm{A}}$ peptide was conjugated to ECH Sepharose $4 \mathrm{~B}$ and CNBr Sepharose 4B (Pharmacia Biotech) according to the manufacturer's instructions. After stabilization, each antiserum was added to peptide-conjugated ECH Sepharose 4B, or peptide-conjugated CNBr Sepharose 4B, and then the mixture was incubated overnight with gentle shaking at $4{ }^{\circ} \mathrm{C}$. The mixture was packed into a column, and non-binding proteins were eluted with $0.1 \mathrm{M} \mathrm{PB}(\mathrm{pH}$ 7.4) containing $0.5 \mathrm{M} \mathrm{NaCl}$. The binding antibody was eluted with $0.1 \mathrm{M}$ glycine- $\mathrm{HCl}$ buffer ( $\mathrm{pH}$ 2.7) containing $0.5 \mathrm{M} \mathrm{NaCl}$ and the elution was neutralized with 0.1 
$\mathrm{N} \mathrm{NaOH}$. The collected solution was dialyzed against distilled water and then freeze-dried using a VC-36N centrifugal concentrator (Taitec Corporation, Koshigaya).

\section{Western blotting}

Solubilization of endothelin receptors from the kidney was performed according to the method described by Kozuka et al. (1991). Briefly, two rat kidneys were placed on a metal plate on ice and $2 \mathrm{~mm}$ sagittal sections were cut by hand. The renal cortex was dissected out with the aid of a stereoscopic microscope. Fragments of the cortex (about $560 \mathrm{mg}$ wet weight) were homogenized in $1 \mathrm{~m} l$ of a $20 \mathrm{mM}$ Tris- $\mathrm{HCl}$ buffer (pH7.4) containing 1 $\mathrm{mM}$ EDTA, $0.2 \mathrm{mM}$ phenylmethylsulfonyl fluoride, 10 $\mu \mathrm{g} / \mathrm{m} l$ pepstatin, and $10 \mu \mathrm{g} / \mathrm{m} l$ leupeptin (solution A). The sample was then centrifuged at $10,000 \mathrm{xg}$ for $1 \mathrm{hr}$ at $4{ }^{\circ} \mathrm{C}$. The pellet was suspended and washed twice with the same solution, and then further washed twice with $20 \mathrm{mM}$ PB ( $\mathrm{pH} 7.4$ ) containing $130 \mathrm{mM} \mathrm{NaCl}, 1 \mathrm{mM}$ EDTA, $0.2 \mathrm{mM}$ phenylmethylsulfonyl fluoride, $10 \mu \mathrm{g} /$ $\mathrm{m} l$ pepstatin, and $10 \mu \mathrm{g} / \mathrm{m} l$ leupeptin (solution B). The final pellet was added to $1 \mathrm{~m} l$ of solution B containing $0.25 \% 3$ [(3-cholamidopropyl) dimethylammonio]-1propanesulfonate and $0.4 \%$ digitonin and left for $12 \mathrm{~h}$ at $4{ }^{\circ} \mathrm{C}$. The supernatant (designated here as the CHAPS fraction) was added to an equivalent volume of Laemmli's sample buffer (Laemmli, 1970). These samples were analyzed by sodium dodecyl sulfate-polyacrylamide gel $(12.5 \%)$ electrophoresis (SDS-PAGE). After SDSPAGE, separated proteins were transferred to Clear Blot Membrane-p (Atto Corporation, Tokyo) and probed with the affinity-purified antibody $(5 \mu \mathrm{g} / \mathrm{m} l)$ in PB containing

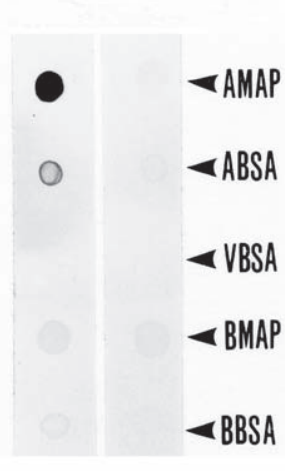

A B

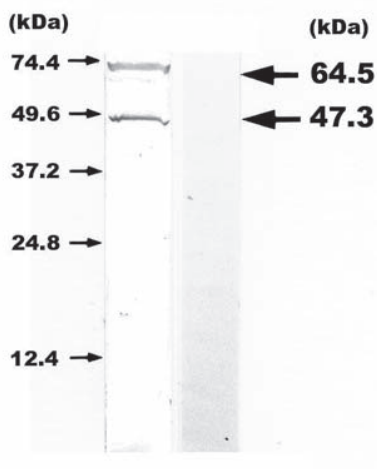

C D

Fig. 1. Larsson's spot test (A and B) and Western blots of the CHAPS fraction of the rat kidney ( $\mathbf{C}$ and $\mathbf{D})$. Lane $\mathbf{A}$ was stained with anti-ETA serum and lane $\mathbf{B}$ was stained with preimmune serum. Lane $\mathbf{C}$ was stained with affinity-purified antiETA antibody and lane $\mathbf{D}$ was processed from the secondary antibody. The spots indicated by arrowheads on the right side of lane B show MAP-modified ETA peptide (AMAP), BSAconjugated $\mathrm{ET}_{\mathrm{A}}$ peptide (ABSA), BSA-conjugated argininevasopressin (VBSA), MAP modified ETв peptide (BMAP) and BSA-conjugated ЕТв peptide (BBSA), respectively. Small arrows on the left side of lane $\mathbf{C}$ indicate the positions of marker proteins at 74.4, 49.6, 37.2, 24.8, and $12.4 \mathrm{kDa}$ (top to bottom, respectively). Large arrows on the right side of lane D indicate the immunoreactive bands that have migrated to approximately $64.5 \mathrm{kDa}$ (higher) and $47.3 \mathrm{kDa}$ (lower).

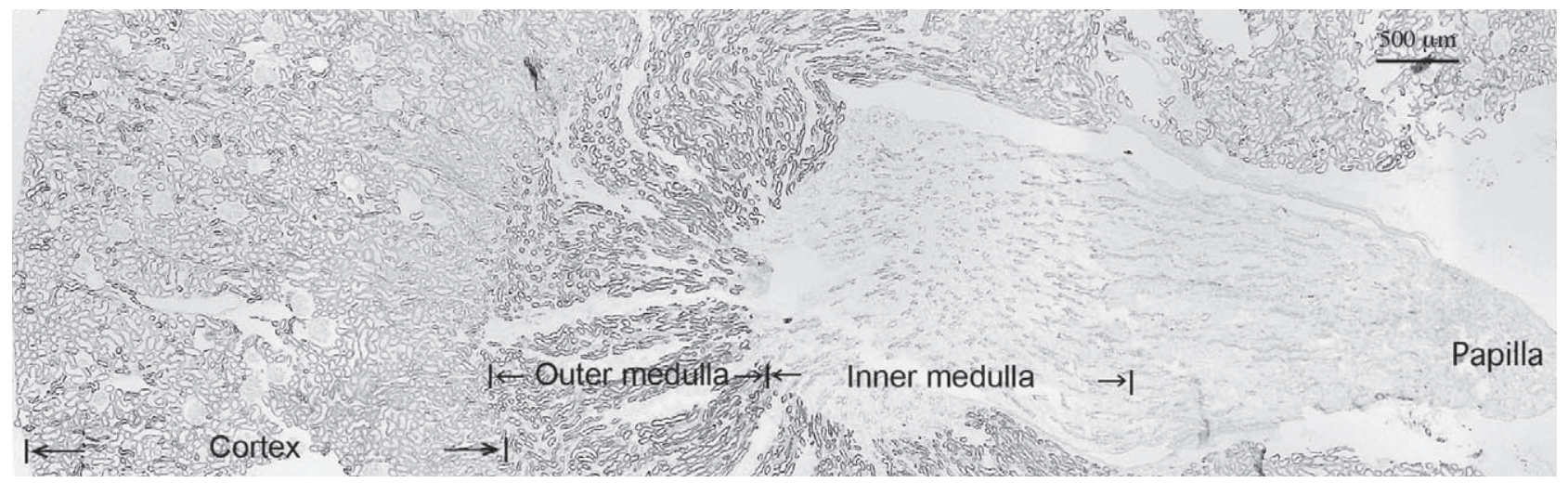

Fig. 2. Photomontage showing the overall distribution of ETA receptor-like immunoreactivity in a coronal section of the rat kidney. Scale bar: $500 \mu \mathrm{m}$ 

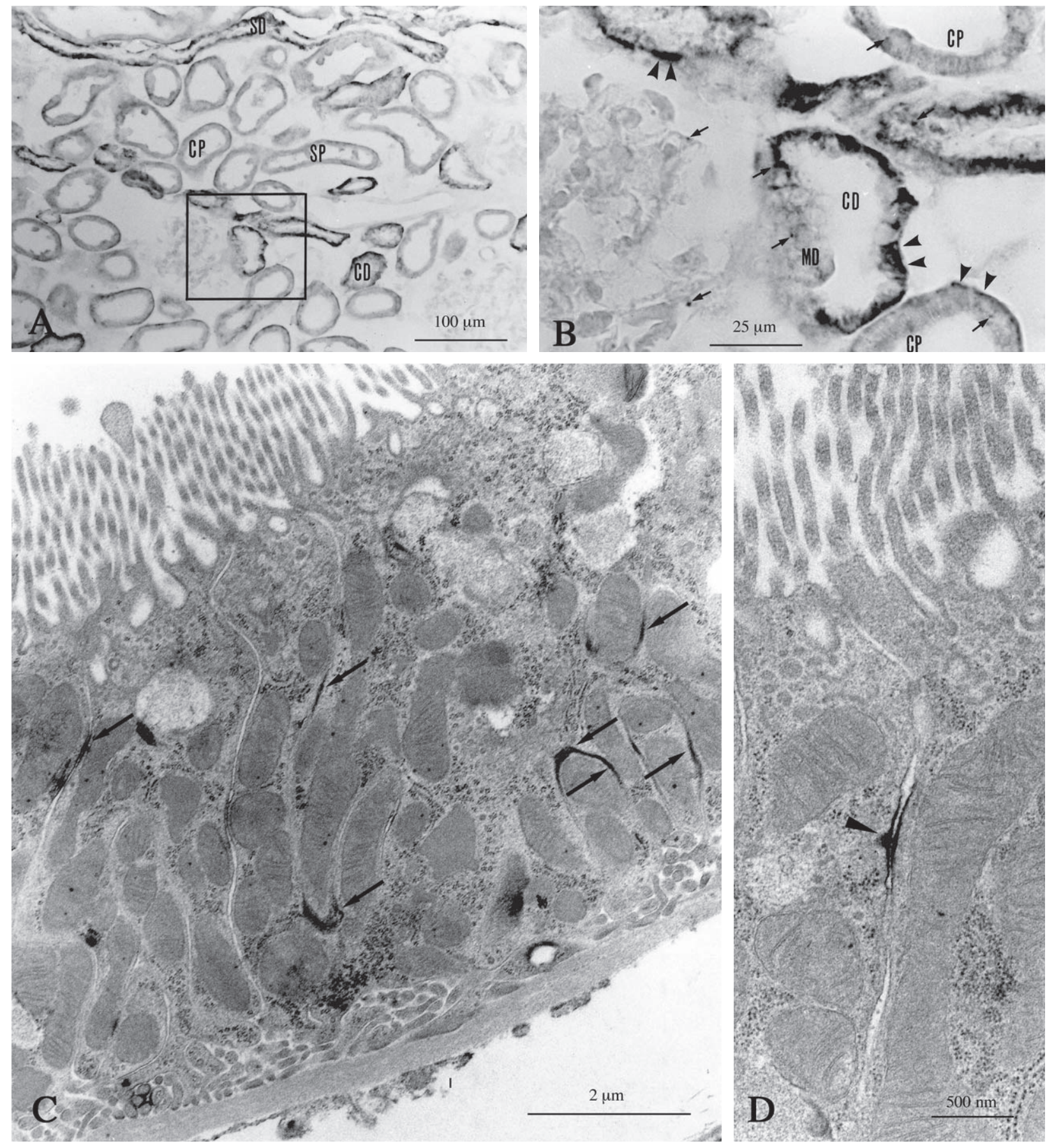

Fig. 3. Light micrographs (A and $\mathbf{B})$ showing ETA-IR in the renal cortex, and electron micrographs $(\mathbf{C}$ and $\mathbf{D})$ showing ETA-IR in the proximal tubular cells. The boxed area in $\mathbf{A}$ indicates the magnified area shown in $\mathbf{B}$. Arrowheads in $\mathbf{B}$ indicate ETA-IR in the basal portion of renal tubules. Arrows in $\mathbf{B}$ indicate immunoreactive puncta. Arrows in $\mathbf{C}$ indicate DAB deposition on part of the cytoplasmic membrane of the basal infolding. Arrowhead in $\mathbf{D}$ indicates an immuno-positive membrane pit. $\mathrm{CD}$ : convoluted portion of the distal tubules, CP: convoluted portion of the proximal tubules, MD: macula densa, SD: straight portion of the distal tubules, SP: straight portion of the proximal tubules. Scale bars: $100 \mu \mathrm{m}$ (A), $25 \mu \mathrm{m}(\mathrm{B}), 2 \mu \mathrm{m}$ (C), $500 \mathrm{~nm}$ (D) 

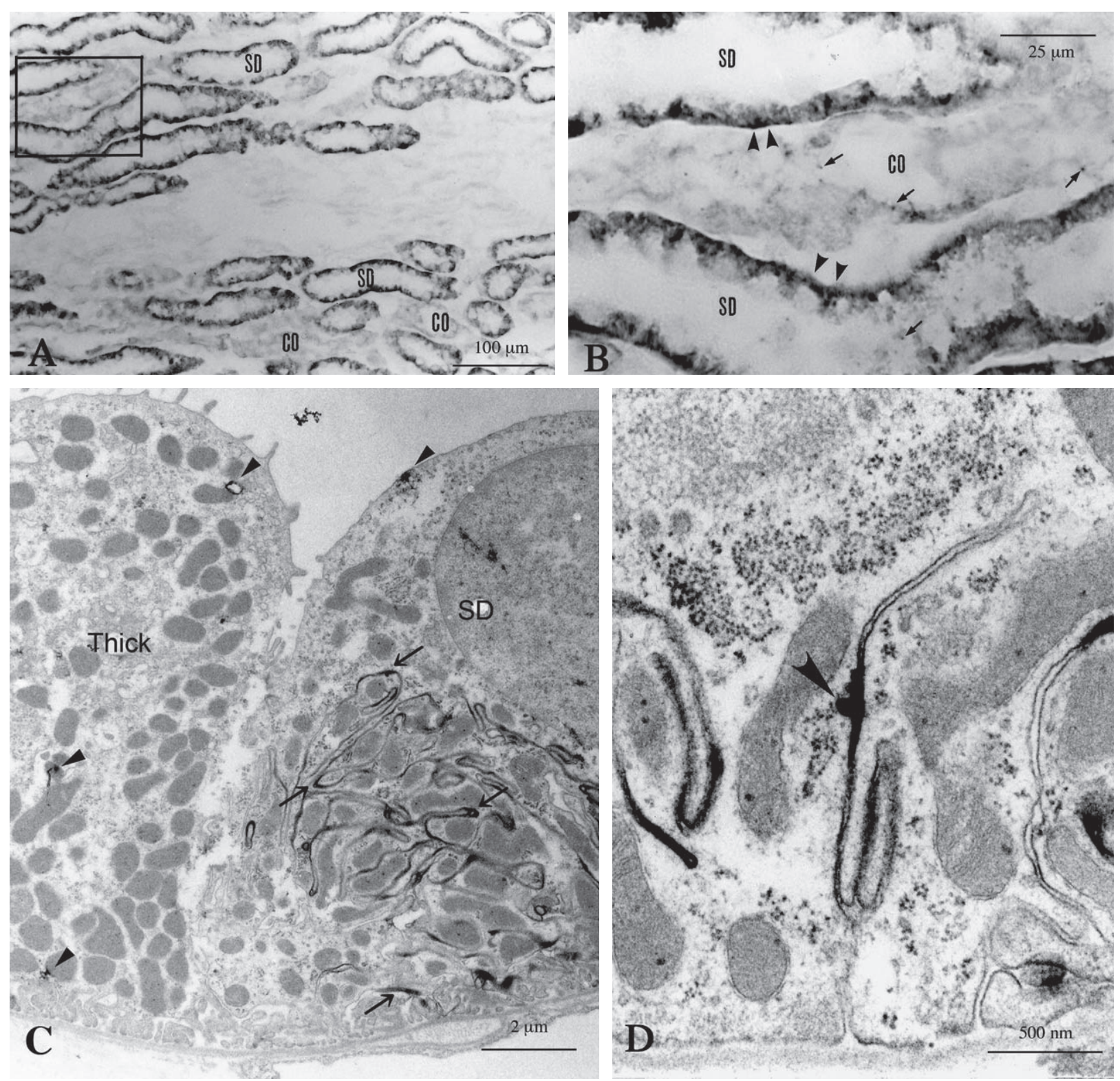

Fig. 4. Light micrographs (A and $\mathbf{B})$ showing $\mathrm{ET}_{\mathrm{A}-\mathrm{IR}}$ in the outer medulla and electron micrographs $(\mathbf{C}$ and $\mathbf{D})$ showing $\mathrm{ET}_{\mathrm{A}-}$ IR in the transitional area from the ascending thick portion of Henle's loop to the distal tubules. The boxed area in $\mathbf{A}$ indicates the magnified area shown in B. Arrowheads in $\mathbf{B}$ indicate ETA-IR in the basal side of renal tubules. Arrows in $\mathbf{B}$ indicate immunoreactive puncta. Arrows in $\mathbf{C}$ indicate DAB deposition on part of the cytoplasmic membrane of basal infolding. Arrowheads in $\mathbf{C}$ indicate coagulation of DAB deposition within cytoplasm in a cell located in the thick portion of Henle's loop (Thick) and a cell located in the straight portion of the distal tubules (SD). The arrowhead in D indicates an immunopositive membrane pit. CO: collecting ducts, SD: straight portion of the distal tubules. Scale bars: $100 \mu \mathrm{m}(\mathrm{A}), 25 \mu \mathrm{m}(\mathrm{B}), 2$ $\mu \mathrm{m}(\mathrm{C}) 500 \mathrm{~nm}(\mathrm{D})$ 
$0.9 \%$ saline (PBS) and 3\% BSA. Probed membranes were then incubated with biotinylated anti-guinea pig IgG $(1: 1,000$, Vector) and ABC complex $(1: 1,000)$ diluted in PBS containing $1 \%$ BSA and finally reacted with $0.02 \%$ DAB solution containing $0.005 \%$ hydrogen peroxide and $0.6 \%$ ammonium nickel sulfate for 5-10 min. Molecular marker proteins (cytochrome c, monomer to hexamer, Oriental East Co., Ltd., Osaka) were also electrophoresed simultaneously.

\section{Immunocytochemistry}

Seven male Wistar rats $(150-250 \mathrm{~g})$ were deeply anesthetized with pentobarbital sodium and perfused with $4 \%$ paraformaldehyde and $0.2 \%$ picric acid in $0.1 \mathrm{M} \mathrm{PB}$ ( $\mathrm{pH}$ 6.9). The kidneys were dissected out and post-fixed in the same fixative for $24 \mathrm{~h}$ at $4{ }^{\circ} \mathrm{C}$, and $8 \mu \mathrm{m}$ sections were then cut with an HM505E cryostat (MICROM, Walldorf, Germany). Immunocytochemical procedures for light and electron microscopies were carried out according to our routine methods (Yamamoto et al., 1992). Briefly, sections were pretreated with $1 \%$ hydrogen peroxide in methanol for $10 \mathrm{~min}$ to block endogenous peroxidase activity and with $3 \%$ BSA in PBS for 30 min to prevent non-specific protein binding to the sections. They were incubated with the affinity-purified antibody $(10 \mu \mathrm{g} / \mathrm{m} l)$ diluted in PBS containing 1\% BSA (PBS-BSA) for 2 days at $4{ }^{\circ} \mathrm{C}$. After washing in PBS-BSA, the sections were incubated with biotinylated anti-guinea pig $\operatorname{IgG}(1: 100)$ and then $\mathrm{ABC}(1: 200)$ for $1 \mathrm{~h}$ each at room temperature. After washing again in PBS-BSA, the sections were incubated with $0.02 \%$ DAB solution containing $0.005 \%$ hydrogen peroxide for 5-10 min. Sections adjacent to those used for light microscopic immunocytochemistry were stained with hematoxylin and eosin to identify the segments of the urinary tubules and their locations. For electron microscopy, $20 \mu \mathrm{m}$ sections were processed as described above. After incubation with DAB solution, they were fixed in $1 \%$ osmium tetroxide for $2 \mathrm{~h}$ at room temperature, dehydrated, and embedded in Quetol-812
(Nisshin EM Co., Ltd., Tokyo). Ultrathin sections were mounted on nickel grids, counterstained slightly with uranyl acetate and lead citrate, and examined with a JEM1220 electron microscope (JEOL, Tokyo). Antibody characteristics were further tested by Western blots of the CHAPS fraction of the rat kidney. Immunocytochemical controls were prepared by omitting the primary antibody or by incubating with the antibody preabsorbed with either the ETA peptide $(50 \mu \mathrm{g} / \mathrm{m} l)$ or the MAP-modified peptide $(20 \mu \mathrm{g} / \mathrm{m} l)$.

\section{Results}

After five booster inoculations, we selected one antiserum based on the staining intensity of kidney sections and the result of the Larsson's spot tests. This antiserum recognized MAP-modified $\mathrm{ET}_{\mathrm{A}}$ peptide, and $\mathrm{ET}_{\mathrm{A}}$ peptideconjugated with BSA (Fig. 1A). However, the antiserum labeled neither MAP-modified ETв, ЕTв peptideconjugated with BSA, nor AVP-conjugated with BSA (Fig. 1B). The selected antiserum was affinity purified using synthetic $\mathrm{ET}_{\mathrm{A}}$ peptide-conjugated ECH Sepharose 4B, or CNBr Sepharose 4B. Western blot analyses using the CHAPS fraction from rat kidney indicated that the

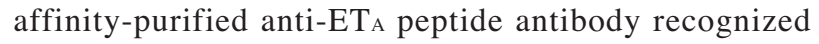
two bands, a major band of approximately $47.3 \mathrm{kDa}$ and a minor band of $64.5 \mathrm{kDa}$ (Fig. 1C, D).

At the light microscopic level, ETA receptor-like immunoreactivity $\left(\mathrm{ET}_{\mathrm{A}}-\mathrm{IR}\right)$ was seen in the renal tubules and collecting ducts but only in part of Henle's loop (data not shown). Under low magnification, the most intense immunoreactivity was seen in the outer medulla and secondarily in the cortex (Fig. 2). In the renal cortex, faint $\mathrm{ET}_{\mathrm{A}}$-IR was present in the proximal tubules, with intense staining in the distal tubules (Fig. 3A, B). In the proximal tubules, including the convoluted and straight portions, $\mathrm{ET}_{\mathrm{A}}$-IR tended to be restricted to the basal side of tubular cells. In addition, immunoreactive puncta were

Fig. 5. Light micrographs (A and $\mathbf{B})$ showing $\mathrm{ET}_{\mathrm{A}-\mathrm{IR}}$ in the inner medulla, and electron micrographs showing $\mathrm{ET}_{\mathrm{A}-}$ IR in the collecting duct cells ( $\mathbf{C}$ and $\mathbf{D})$, a thin portion of Henle's loop (E), and an endothelial cell of a blood capillary (F). The boxed area in A indicates the magnified area shown in B. Arrowheads in B indicate ETA-IR in the basal portion of collecting ducts. Arrows in $\mathbf{C}$ and $\mathbf{D}$ indicate DAB deposition on part of the cytoplasmic membrane of the basal infolding, The arrowhead in $\mathbf{D}$ indicates an immuno-positive membrane pit. The cell lining a thin portion of Henle's loop (Thin) and an endothelial cell of a blood capillary (EC) seem to be immuno-negative. Some ribosomes in $\mathbf{F}$ show nonspecific staining. CO: collecting ducts. Scale bars: $100 \mu \mathrm{m}$ (A), $25 \mu \mathrm{m}$ (B), $2 \mu \mathrm{m}$ (C) and $500 \mathrm{~nm}$ (D) 

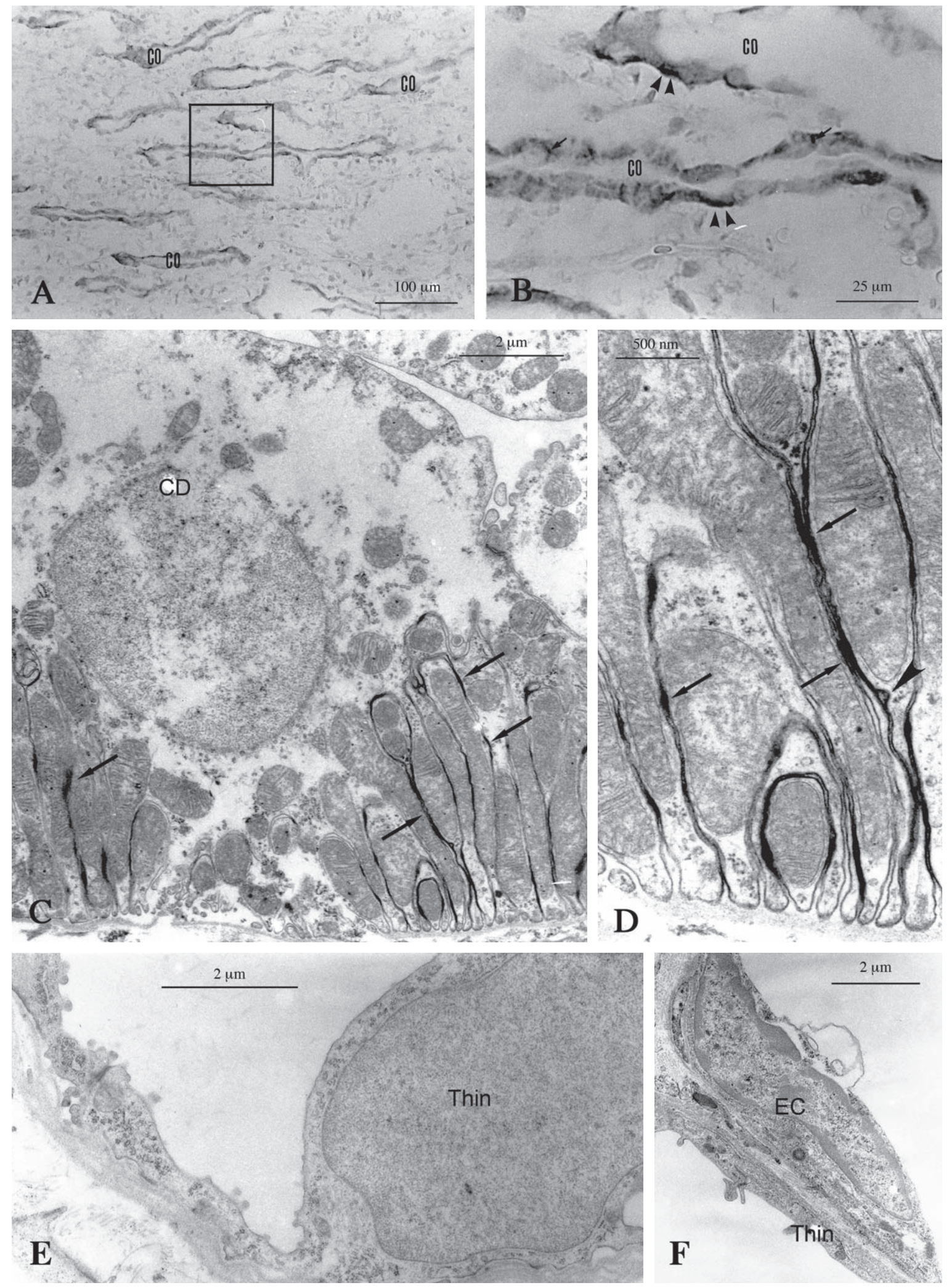

Fig. 5. Legend on the opposite page. 
sometimes scattered on the middle portion but were rare on the luminal side of tubular cells (Fig. 3B). By electron microscopic analysis, DAB deposition was seen on part of the cytoplasmic membrane comprising the basal infolding and also in part of the lateral cytoplasmic membrane adjacent to neighboring tubular cells (Fig. 3C, D). Immunopositive membrane pits were sometimes observed on parallel portions of the cytoplasmic membran (Fig. 3D). In the distal tubules of the renal cortex, intense $\mathrm{ET}_{\mathrm{A}-}$ IR was seen on the basal side of tubular cells, wider than in the proximal tubules, but the luminal side was generally free of $\mathrm{ET}_{\mathrm{A}-\mathrm{IR}}$ (Fig. 3B). In the macula densa, staining was not so evident, but a few immunoreactive puncta were seen in the basal side of the cells (Fig. 3B).

In the outer medulla, intense $\mathrm{ET}_{\mathrm{A}-\mathrm{IR}}$ was seen in the straight portion of the distal tubules (Fig. 4A, B). Staining profiles in these tubules were similar to those seen in cortical distal tubules (Fig. 3A, B). At the electron microscopic level, DAB deposition was seen to some extent on the cytoplasmic membrane forming the basal infoldings of the distal tubules (Fig. 4C, D). Immunoreactive membrane pits were often seen on these immuno-positive membranes (Fig. 4D). A considerable part of Henle's loop seemed to be immunonegative for the $\mathrm{ET}_{\mathrm{A}}$ antibody although some DAB deposition was observed within the cytoplasm (Fig. 4C). The collecting ducts that intermingled with intensely stained distal tubules contained a few immunoreactive puncta (Fig. 4B).

In the inner medulla, intense ETA-IR was seen in the collecting ducts with staining profiles similar to those seen in the distal tubules (Fig. 5A, B). The collecting ducts in this area showed more intense staining than those in the outer medulla. In the collecting ducts, some $\mathrm{DAB}$ deposition was seen on the cytoplasmic membrane of the basal infoldings (Fig 5C, D) and part of the lateral membrane (data not shown), similar to that seen in the proximal tubules. Other areas of the inner medulla consisting of blood vessels and a thin portion of Henle's loop seemed to be immuno-negative (Fig. 5E, F).

There were no differences in staining profiles between antibodies that had been affinity-purified with ECH Sepharose 4B and these with CNBr Sepharose 4B. The staining profiles produced by these antibodies were abolished by preabsorption with $\mathrm{ET}_{\mathrm{A}}$ peptide or with MAP-modified ETA peptide (data not shown). There was no immunostaining in the sections processed with preimmune serum or the secondary antibody (not shown).

\section{Discussion}

The specificity of the antibody produced here was confirmed by the disappearance of the staining profiles following preabsorption with $\mathrm{ET}_{\mathrm{A}}$ peptide or MAPmodified $\mathrm{ET}_{\mathrm{A}}$ peptide. The anti-ETA antiserum subjected to affinity purification recognized the MAP-modified ET $_{\mathrm{A}}$ peptide, and the peptide conjugated to BSA, but not the MAP-modified ЕTв peptide or, by Larson's spot test, the peptide conjugated to BSA. Western blot analysis indicated that the anti-ET A $_{\mathrm{A}}$ antibody detected two bands from the CHAPS fraction of the rat kidney. The lower band $(47.3 \mathrm{kDa})$ was close to the deduced molecular weight from cloned cDNA of the human ETA receptor (427 amino-acid residues with a relative $M r$ of 48,722 by Adachi et al., 1991), bovine $\mathrm{ET}_{\mathrm{A}}$ receptor (427 aminoacid residues with a relative $M r$ of 48,516 by Arai et al., 1990), and rat $\mathrm{ET}_{\mathrm{A}}$ receptor (426 amino-acid residues with no description about $M r$ by Lin et al., 1991). The higher band $(64.5 \mathrm{kDa})$ might be a glycosylated form. In fact, the presence of higher species $(53 \mathrm{kDa}$ by Watanabe $e t$ al., 1989 and $73 \mathrm{kDa}$ by Martin et al., 1990) of the $\mathrm{ET}_{\mathrm{A}}$ receptor, having a higher affinity for ET-1 than ET-3, has been documented by SDS-PAGE electrophoresis.

It is well known that ET induces natriuresis, acting locally in a paracrine and/or autocrine mode, by reducing $\mathrm{Na}^{+}, \mathrm{K}^{+}$-ATPase activity in the rat proximal tubule (Garvin and Sanders,1991) and in the rabbit inner medullary collecting duct (IMCD) (Zeidel et al., 1989). However, the identities of the ET receptors that mediate ET-induced inhibition of sodium transport are uncertain. The exception is in dogs, in which there is evidence that the ЕТв receptor is involved (Brooks et al., 1994). In our electron microscopic analysis, we found $\mathrm{ET}_{\mathrm{A}}$ receptorlike immunoreactivity in the basal infoldings of tubular cells in the proximal and distal tubules as well as of inner medullary collecting ducts (IMCD) cells. These membranes are known to contain $\mathrm{Na}^{+}, \mathrm{K}^{+}$-ATPase. In agreement with our data, ET binding sites have also been demonstrated on basal infoldings of these cells by a radiobinding study (Yukimura et al., 1996). Thus, the ETA receptor may be involved in the ET-mediating reduction of $\mathrm{Na}^{+}, \mathrm{K}^{+}$-ATPase activity. We cannot, however, exclude the possible involvement of $\mathrm{ET}_{\mathrm{B}}$ receptors in this $\mathrm{ET}$ function, because both $\mathrm{ET}_{\mathrm{A}}$ and $\mathrm{ET}_{\mathrm{B}}$ receptors were implicated by binding studies and reverse transcriptionPCR (RT-PCR) in the rat IMCD (Kohan et al., 1992). The proportion of $\mathrm{ET}_{\mathrm{A}}$ to $\mathrm{ET}_{\mathrm{B}}$ receptors was found by binding studies to be $2: 3$ in the basolateral membrane in the renal cortex (Edwards et al., 1998). Furthermore, we also found $\mathrm{ET}_{\mathrm{B}}$ receptor-like immunoreactivity in the rat proximal tubules and IMCD in a preliminary study (Yamamoto 
and Uemura, 1998), although the stained areas were far smaller than in the glomeruli (Yamamoto et al., 2002). Further studies are needed to clarify the subtype(s) of ET receptors involved in the inhibition of $\mathrm{Na}^{+}, \mathrm{K}^{+}$-ATPase activity.

It has been shown that ET inhibits AVP-dependent cAMP accumulation in the rat collecting duct, possibly by the inhibition of adenylate cyclase activity (Tomita et al., 1990). Furthermore, ET inhibited AVP-stimulated water permeability in the rat collecting ducts (Oishi et al., 1991; Tomita et al., 1993). However, conflicting results have been obtained regarding the receptor subtype involved in the inhibition of AVP: Nadler and Zimpelmann (1992) suggested that this occurred via the ET $_{\mathrm{A}}$ receptor, whereas Edwards et al. (1993) suggested it was via the $\mathrm{ET}_{\mathrm{B}}$ receptor. Moreover, the presence of $\mathrm{ET}_{\mathrm{B}}$ receptor mRNA, but not $\mathrm{ET}_{\mathrm{A}}$ receptor mRNA, has been shown by RT-PCR in the IMCD (Terada et al., 1992) and inner and outer medullary collecting ducts (Chow et al., 1995). Another study, however, found both $\mathrm{ET}_{\mathrm{A}}$ and $\mathrm{ET}_{\text {в }}$ receptors in the IMCD (Kohan et al., 1992). A recent immunohistochemical study showed the presence of the $\mathrm{ET}_{\mathrm{A}}$ receptor in the distal tubules and cortical collecting ducts, but not in the outer medullary collecting ducts (Wendel et al., 2006). In contrast, the present data showed $\mathrm{ET}_{\mathrm{A}}$ receptor-like immunoreactivity in the outer medullary collecting ducts and IMCD. The collecting duct, especially the IMCD, is the major nephron site of ET-1 synthesis and binding. Moreover, a collecting ductspecific knockout of the $\mathrm{ET}_{\mathrm{A}}$ receptor shows altered renal AVP responsiveness (Ge et al., 2005). Taking all these results into account, both types of ET receptor may be present in the IMCD and involved in ET modulation of the AVP function. However, this issue requires further clarification. ET may stimulate ET receptors on the basal infoldings to influence, directly or indirectly, $\mathrm{Na}^{+}, \mathrm{K}^{+}-$ ATPase, and AVP receptors.

It is well known that stimulation of the $\mathrm{ET}_{\mathrm{A}}$ receptor leads to the vasoconstriction of preglomerular arteries and efferent arterioles (Lanese and Conger, 1993) and that stimulation of the ЕTв receptor is able to cause both vasodilation - with the release of prostacyclin and nitric oxide-and vasoconstriction without such a release (Hyslop and de Nucci, 1992). Immunohistochemical studies have indicated the presence of the ЕTв receptor over the glomerular and peritubular capillaries (Hagiwara et al., 1993; Yamamoto and Uemura, 1998; Wendel et al., 2006) and on podocytes (Yamamoto et al., 2002). On the other hand, the present study did not detect ETA-IR in the renal vascular system, but Wendel and co-workers found it in the renal vascular system, in addition to the collecting ducts (Wendel et al., 2006). This discrepancy may be a consequence of the antibodies utilized, because Western blot analysis indicated slight differences between the antibody used here and the antiserum used by Wendel and co-workers in the protein species recognized. An alternative explanation may lie in the fact that the antibody used here labeled only a subtype of the $\mathrm{ET}_{\mathrm{A}}$ receptor. The presence of a subtype of the $\mathrm{ET}_{\mathrm{A}}$ receptor, designated $\mathrm{ET}_{\mathrm{Ax}}$, has been demonstrated in the Xenopus heart and oocyte follicle (Kumar et al., 1993, 1994). The binding properties of the ETAX receptor for ET$1, \mathrm{ET}-3$, and sarafotoxin $6 \mathrm{c}$ (a selective agonist for the ET $\mathrm{B}$ receptor) were similar to those of the $\mathrm{ET}_{\mathrm{A}}$ receptor, but the $\mathrm{ET}_{\mathrm{AX}}$ receptor had a different binding property for BQ123 (a selective antagonist for the ETA receptor) compared with the $\mathrm{ET}_{\mathrm{A}}$ receptor. Although the existence of the ETAx receptor in mammalian species has not yet been confirmed, the presence of a novel ET-3 binding site-which has a different binding profile from the traditional $\mathrm{ET}_{\mathrm{A}}$ or $\mathrm{ET}_{\mathrm{B}}$ receptor and highly binds a $\mathrm{ET}_{\mathrm{A}}$ antagonist, A-127722-has been demonstrated in the inner medulla of ЕТв receptor-deficient rats (Taylor et al., 2003). Therefore, it is possible that the antibody used here recognized a subtype of mammalian ET receptors for which amino acid sequences have not yet been clarified.

\section{References}

Adachi M, Yang YY, Furuichi Y, Miyamoto C: Cloning and characterization of cDNA encoding human A-type endothelin receptor. Biochem Biophys Res Commun 180: 1265-1272 (1991).

Arai H, Hori S, Aramori I, Ohkubo H, Nakanishi S: Cloning and expression of a cDNA encoding an endothelin receptor. Nature 348: $730-732$ (1990).

Bax WA, Saxena PR: The current endothelin receptor classification: time for reconsideration? Trends Pharmacol Sci 15: 379-386 (1994).

Brooks DP, DePalma PD, Pullen M, Nambi P: Characterization of canine renal endothelin receptor subtypes and their function. J Pharmacol Exp Ther 268: 1091-1097 (1994).

Chow LH, Subramanian S, Nuovo G.J, Miller F, Nord EP: Endothelin receptor mRNA expression in reanl medulla identified by in situ RT-PCR. Am J Physiol 269: F449F457 (1995).

Edwards RM, Stack EJ, Pullen M, Nambi P: Endothelin inhibits vasopressin action in rat inner medullary collecting duct via the ETв receptor. J Pharmacol Exp Ther 267: 1028-1033 (1993).

Edwards RM, Trizna W, Stack EJ: $\left[{ }^{125}\right.$ I] endothelin1 binding to renal brush border and basolateral membranes. Eur J Pharmacol 345: 229-232 (1998). 
Garvin J, Sanders K: Endothelin inhibits fluid and bicarbonate transport in part by reducing $\mathrm{Na}^{+} / \mathrm{K}^{+}$ ATPase activity in the rat proximal straight tubule. $J$ Am Soc Nephrol 2: 976-982 (1991).

Ge Y, Stricklett PK, Hughes AK, Yanagisawa M, Kohan DE: Collecting duct-specific knockout of the endothelin A receptor alters renal vasopressin responsiveness, but not sodium excretion or blood pressure. Am J Phsiol Renal Physiol 289: F629-F698 (2005).

Hagiwara H, Nagasawa T, Yamamoto T, Lodhi KM, Ito $\mathrm{T}$, Takemura N, Hirose S: Immunochemical characterization and localization of endothelin ETB receptor. Am J Physiol 264: R777-R783 (1993).

Hori S, Komatsu Y, Shigemoto R, Mizuno N, Nakanishi $\mathrm{S}$ : Distinct tissue distribution and cellular localization of two messenger ribonucleic acids encoding different subtypes of rat endothelin receptors. Endocrinology 130: 1885-1895 (1992).

Hyslop S, De Nucci G.: Vasoactive mediators released by endothelins. Pharmacol Res 26: 223-242 (1992).

Kakui S, Mawatari K, Ohnishi T, Niwa Y, Tanoue N, Harada N, Tkahashi A, Izumi K, Nakaya Y: Localization of the 31-amino-acid endohelin-1 in hamster tissue. Life Sci 74: 1435-1443 (2004).

Karne S, Jayawickreme CK, Lerner MR: Cloning and characterization of an endothelin-3 specific receptor (ETC receptor) from Xenopus laevis dermal melanophores. J Biol Chem 268: 19126-19133 (1993).

Kohan DE, Hughes AK, Perkins SL: Characterization of endothelin receptors in the inner medullary collecting duct of the rat. J Biol Chem 267: 12336-12340 (1992).

Kozuka, M., Ito, T., Hirose, S., Lodhi, K.M., Hagiwara, $\mathrm{H}$ : Purification and characterization of bovine lung endothelin receptor. J. Biol. Chem. 266, 16892-16896 (1991).

Kuc RE, Davenport AP: Comparison of endothelin$A$ and endothelin-B receptor distribution visualized by radioligand binding versus immunocytochemical localization using subtype selective antisera. $J$ Cardiovasc Pharmacol 44 (Suppl 1): S224-S226 (2004).

Kumar CS, Nuthulaganti P, Pullen M, Nambi P: Novel endothelin receptors in the follicular membranes of Xenopus laevis oocytes mediate calcium responses by signal transduction through gap junctions. Mol Pharmacol 44: 153-157 (1993).

Kumar C, Mwangi V, Nuthulaganti P, Wu H-L, Pullen M, Brun K, Aiyar H, Morris RA, Naughton R, Nambi P: Cloning and characterization of a novel endothelin receptor from Xenopus heart. J Biol Chem 269: 1341413420 (1994).
Laemmli UK: Cleavage of structural proteins during the assembly of the head of bacteriophage T4. Nature 227: 680-685 (1970).

Lanese DM, Conger JD: Effects of endothelin receptor antagonists on cyclosporine-induced vasoconstriction in isolated rat renal arterioles. J Clin Invest 91: 21442149 (1993).

Larsson L-I: A novel immunocytochemical model system for specificity and sensitivity screening of antisera against multiple antigens. J Histochem Cytochem 29: 408-410 (1981).

Lin HY, Kaji EH, Winkel GK, Ives HE, Lodish HF: Cloning and functional expression of a vascular smooth muscle endothelin 1 receptor. Proc Natl Acad Sci USA 88: 3185-3189 (1991).

Martin ER, Brenner BM, Ballermann BJ: Heterogeneity of cell surface endothelin receptors. J Biol Chem 265: 14044-14049 (1990).

Masaki T, Kimura S, Yanagisawa M, Goto K: Molecular and cellular mechanism of endothelin regulation. Implications for vascular function. Circulation 84: 1457-1468 (1991).

Nadler SP, Zimpelmann JA: Diuresis modulates endothelin (ET) action in rat inner medullary collecting duct (IMCD). J Am Soc Nephrol 3: 796 (1992).

Naruse M, Naruse K, Demura H: Recent advances in endothelin research on cardiovascular and endocrine systems. Endocr J 41: 491-507 (1994).

Oishi R, Nonoguchi H, Tomita K, Marumo F: Endothelin1 inhibits AVP-simulated osmotic water permeability in rat inner medullary collecting duct. Am J Phsiol 261: F951-F956 (1991).

Rubanyi, G.M, Polokoff MA: Endothelins: molecular biology, biochemistry, pharmacology, physiology, and pathophysiology. Pharmacol Rev 46: 325-415 (1994).

Sakurai T, Yanagisawa M, Takuwa Y, Miyazaki H, Kimura S, Goto K, Masaki T: Cloning of a cDNA encoding a non-isopeptide-selective subtype of the endothelin receptor. Nature 348: $732-735$ (1990).

Simonson MS, Dunn MJ: Cellular signaling by peptides of the endothelin gene family. FASEB J 4: 2989-3000 (1990).

Tam JP, Lu YA: Vaccine engineering: enhancement of immunogenicity of synthetic peptide vaccines related to hepatitis in chemically defined models consisting of Tand B-cell epitopes. Proc Natl Acad Sci USA 86: 90849088 (1989).

Taylor TA, Gariepy CE, Pollock DM, Pollock JS: Unique endothelin receptor binding in kidneys of $\mathrm{ET}_{\mathrm{B}}$ receptor deficient rats. Am J Physiol Regul Integr Comp Physiol 284: R674-R681 (2003). 
Terada Y, Tomita K, Nonoguchi H, Marumo F: Different localization of two types of endothelin receptor mRNA in microdissected rat nephron segments using reverse transcription and polymerase chain reaction assay. $J$ Clin Invest 90: 107-112 (1992).

Tomita K, Nonoguchi H, Marumo F: Effects of endothelin on peptide-dependent cyclic adenosine monophosphate accumulation along the nephron segments of the rat. $J$ Clin Invest 85: 2014-2018 (1990).

Tomita K, Nonoguchi H, Terada Y, Marumo F: Effects of ET-1 on water and chloride transport in cortical collecting ducts of the rat. Am J Physiol 264: F690F696 (1993).

Watanabe H, Miyazaki H, Kondoh M, Masuda Y, Kimura S, Yanagisawa M, Masaki T, Murakami K: Two distinct types of endothelin receptors are present on chick cardiac membranes. Biochem Biophys Res Commun 161: 1252-1259 (1989).

Wendel M, Knels L, Kummer W, Koch T: Distribution of endothelin receptor subtypes $\mathrm{ET}_{\mathrm{A}}$ and $\mathrm{ET}_{\mathrm{B}}$ in the rat kidney. J Histochem Cytochem 54: 1193-1203 (2006).
Yamamoto T, Katsumata N, Tachibana K, Friesen HG. Nagy JI: Distribution of a novel peptide in the anterior pituitary, gastric pyloric gland, and pancreatic islets of rat. J Histochem Cytochem 40: 221-229 (1992).

Yamamoto T, Uemura H: Distribution of endothelin-B receptor-like immunoreactivity in rat brain, kidney, and pancreas. J Cardiovasc Pharmacol 31 (Suppl 1): S207S211 (1998).

Yamamoto T, Hirohama T, Uemura H: Endothelin B receptor-like immunoreactivity in podocytes of the rat kidney. Arch Histol Cytol 65: 245-250 (2002).

Yukimura T, Notoya M, Mizojiri K, Mizuhira V, Matsuura T, Ebara T, Miura K, Kim S, Iwao H, Song $\mathrm{K}$ : High resolution localization of endothelin receptors in rat renal medulla. Kidney Int 50: 135-147 (1996).

Zeidel ML, Brady HR, Kone BC, Gullans SR, Brenner BM: Endothelin, a peptide inhibitor of $\mathrm{Na}(+)-\mathrm{K}(+)-$ ATPase in intact renal tubular epithelial cells. Am J Physiol 257: C1101-C1107 (1989). 